\title{
The impact on quality of life from informing diagnosis in patients with cancer: a systematic review and meta-analysis
}

\author{
Miao Wan', Xianggui Luo', Juan Wang², Louis. B Mvogo Ndzana' ${ }^{1}$ Chen Chang ${ }^{3}$, Zhenfen Li ${ }^{3}$ and Jianglin Zhang ${ }^{\text {** }}$
}

\begin{abstract}
Background: The aim of this study was to assess the impact on quality of life from informing patients with cancer of their diagnosis and disease status.

Method: We searched the follow databases, PubMed, CENTRAL (Cochrane Central Register of Controlled Trials), PsycINFO, WEB OF SCIENCE, Embase, CBM (Chinese Biomedical Literature database), WANFANG database (Chinese Medicine Premier), and CNKI (China National Knowledge Infrastructure), using the following terms: neoplasm, cancer, tumor, tumor, carcinoma, disclosure, truth telling, breaking bad news, knowledge, knowing, awareness, quality of life, QOL. Pairs of reviewers independently screened documents and extracted the data, and the meta-analysis was performed using Revman 5.0 software.
\end{abstract}

Results: Eleven thousand seven hundred forty records retrieved from the databases and 23 studies were included in the final analysis. A meta-analysis revealed that there were no differences in either the general quality of life and symptoms of fatigue, pain, dyspnea, insomnia, appetite loss, and diarrhea, between informed and uniformed cancer patients $(P>0.05)$. There were also no differences found between the patient groups in physical function, role function, cognitive activity, and emotional function $(P>0.05)$. In terms of vitality, patients who were completely informed about their diagnosis showed higher vitality than uniformed patients. Uninformed patients seemed to have lower social function scores. Between partly informed and uninformed cancer patients, no differences were found in their general quality of life, function domains, and disease-related symptoms $(P>0.05)$.

Conclusion: Informing cancer patients of their diagnosis may not have a detrimental effect on their quality of life.

Trial registration: CRD42017060073.

Keywords: Diagnosis awareness, Cancer, Diagnosis disclosure, Meta-analysis, Quality of life, Systematic review

\section{Background}

In 2015 , an estimated 17.5 million new cancer cases and 8.8 million cancer deaths occurred worldwide [1]. Health care providers are usually reluctant to inform their patients of a cancer diagnosis [2, 3] and although it is ethical to inform patients of their diagnosis and disease

\footnotetext{
* Correspondence: zhangjlcsu@163.com

'Dermatology Department of Xiangya Hospital, Central SouthUniversity, No.87, Xiangya Road, Kaifu District, Changsha 410000, Hunan Province, China Full list of author information is available at the end of the article
}

status, plenty of physicians and patients' relatives still believe that concealing diagnosis and disease status was significant for a patients' prognosis.

Many researchers are also interested in this topic and one study showed that patients' awareness of disease status significantly increased rates of psychiatric disorders, such as depression and anxiety [4]. Conversely, another study showed that patient awareness of disease status helped to decrease the occurrence of depression and anxiety in patients with end-of-life cancer [5]. A systematic 
review in 2015 tried to confirm the influence of disease status awareness on the quality of life of patients with metastatic cancer, however, only mixed findings were found on the association [6]. There has been no systematic review with meta-analysis to assess the impact of awareness of diagnosis on quality of life (QoL) for patients with cancer.

In this review, we have systematically collected and reviewed studies focusing on the association between diagnosis disclosure and QoL in cancer patients, and have conducted a meta-analysis to quantitatively present this association by pooling effect estimates.

\section{Methods}

Inclusion and exclusion criteria

The following inclusion criteria were used to optimize selection of appropriate articles: articles needed to (1) be written in either English or Chinese; (2) explore the concept of awareness of disease status among cancer patients; (3) explore the impact of disease awareness on patients' quality of life; (4) be randomized controlled studies, cohort studies, or case control studies. The following exclusion criteria were used: (1) the article was a conference abstract; (2) the full text was unavailable.

\section{Patient and public involvement}

No patients were directly involved in this study.

\section{Literature retrieval and screening}

We searched the following databases, PubMed, CENTRAL (Cochrane Central Register of Controlled Trials), PsycINFO, WEB OF SCIENCE, Embase, CBM (Chinese Biomedical Literature database), WANFANG database (Chinese Medicine Premier), and CNKI (China National Knowledge Infrastructure). The terms used were: neoplasm, cancer, tumor, carcinoma, disclosure, truth telling, breaking bad news, knowledge, knowing, awareness, quality of life, and QOL. Reference lists of obtained articles were hand searched and authors were contacted if articles couldn't be easily obtained. Pairs of reviewers independently screened the literature and the third reviewer resolved any disagreements. The systematic review was registered in 2015 with PROSPERO registration number CRD42017060073. A complementary search using the above terms was performed in February 2018.

\section{Data extraction and management}

Pairs of reviewers independently extracted the following data from included studies: first author, publication year, country, journal, the setting where the research was carried out, the time when the study began and ended, the definition of exposure in the research, study design, financial support, conflicts of interests, patients' characteristics, and quality of life. The third reviewer resolved any disagreements.
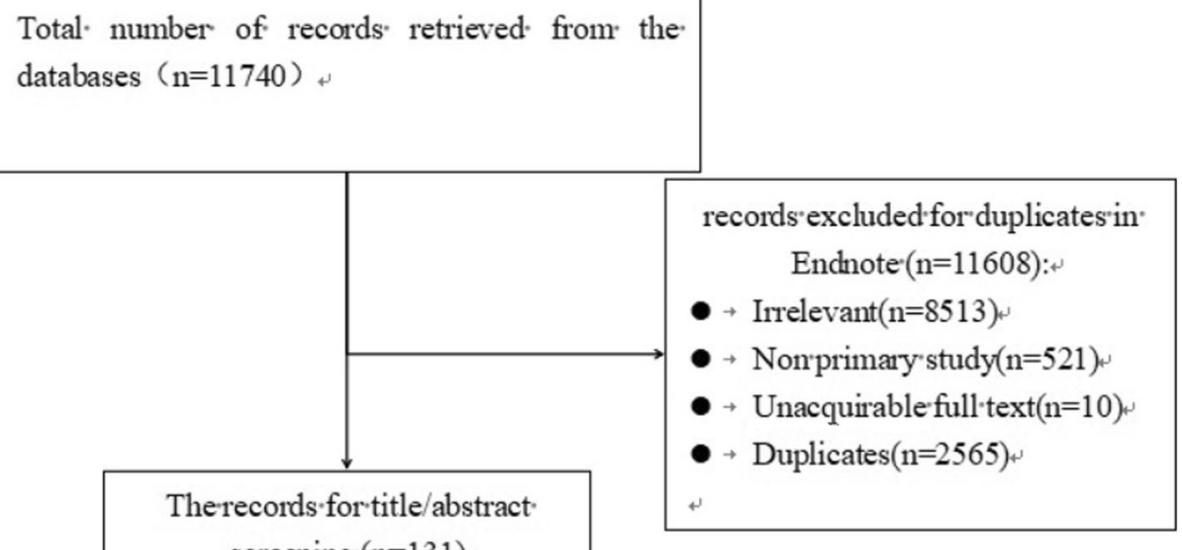

Total number of records'excluded $(n=108)$

- $\rightarrow$ Irrelevant $(\mathrm{n}=74)$

- + Duplicates $(\mathrm{n}=34)$

Finally'included studies $(n=23)$

Fig. 1 Study flow diagram 


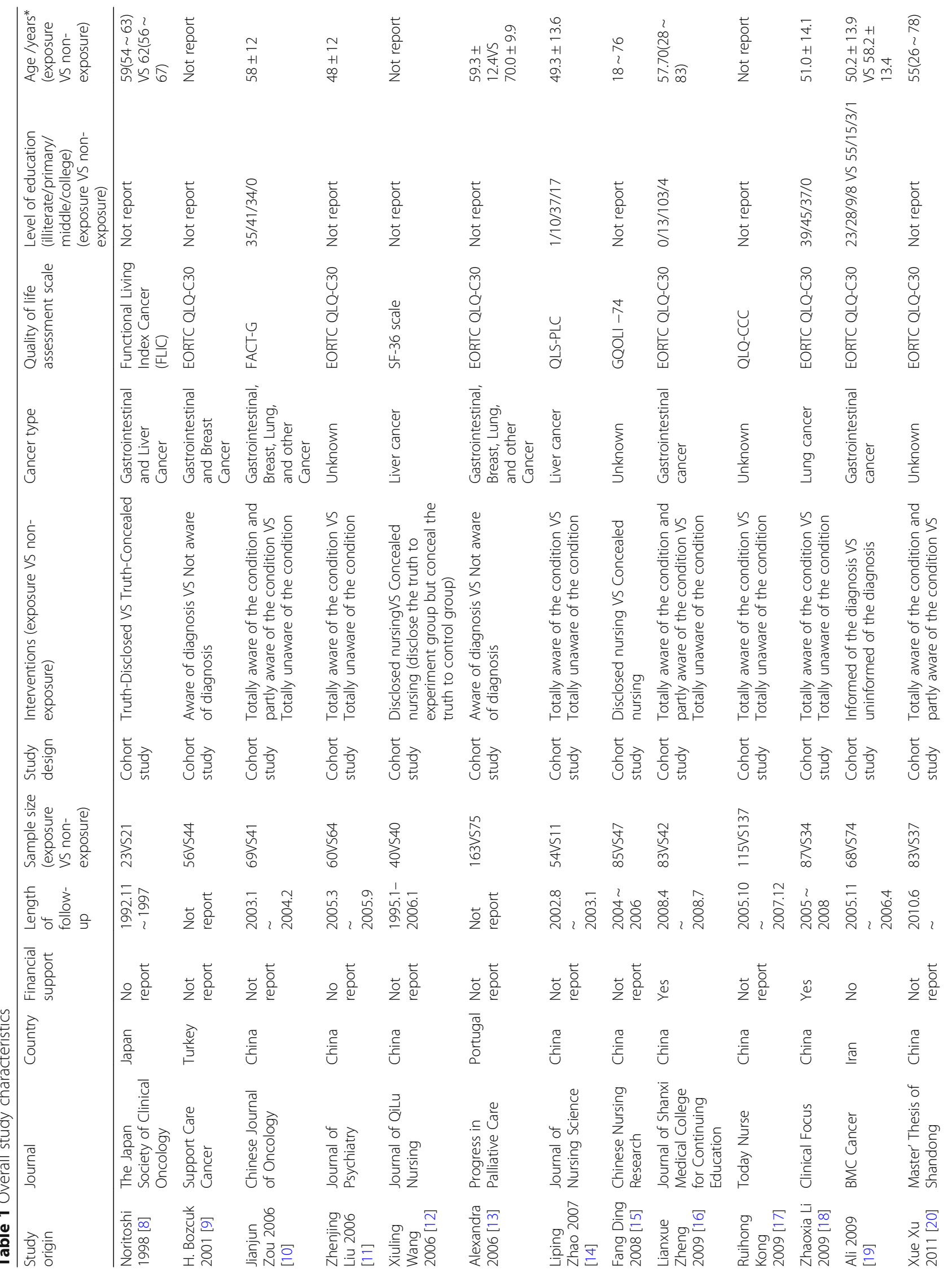




\begin{tabular}{|c|c|c|c|c|c|c|c|c|c|c|}
\hline 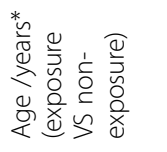 & 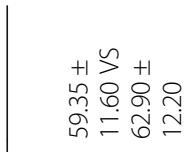 & 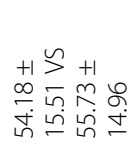 & $\#$ & 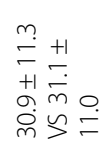 & 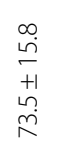 & 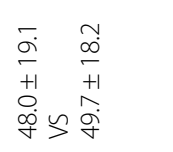 & 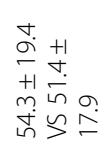 & $\begin{array}{l}\infty \\
\stackrel{\infty}{亡} \\
+ \\
\infty \\
\stackrel{\infty}{\Sigma}\end{array}$ & 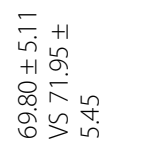 & 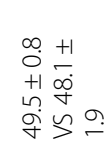 \\
\hline 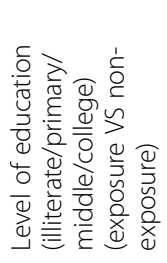 & 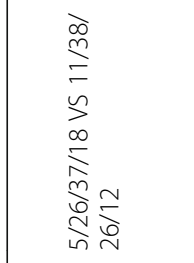 & $\begin{array}{l}\frac{5}{0} \\
\frac{0}{2} \\
\frac{0}{2} \\
\frac{0}{2}\end{array}$ & 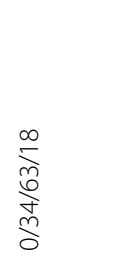 & $\begin{array}{l}\frac{5}{0} \\
\frac{0}{0} \\
\frac{0}{2} \\
\frac{0}{2}\end{array}$ & $\begin{array}{l}\frac{5}{0} \\
\frac{0}{0} \\
\frac{0}{2} \\
\frac{0}{2}\end{array}$ & $\begin{array}{l}\frac{5}{0} \\
\frac{0}{a} \\
\frac{0}{2} \\
\frac{0}{2}\end{array}$ & $\begin{array}{l}\frac{5}{0} \\
\frac{0}{0} \\
\frac{0}{2} \\
\frac{0}{2}\end{array}$ & $\begin{array}{l}\frac{5}{0} \\
\frac{0}{0} \\
\frac{0}{2} \\
\frac{0}{2}\end{array}$ & 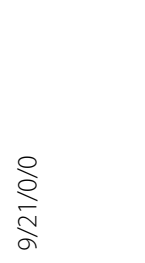 & $\begin{array}{l}\frac{5}{0} \\
\frac{0}{0} \\
\frac{0}{2}\end{array}$ \\
\hline 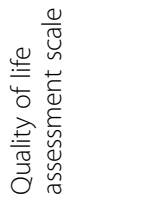 & 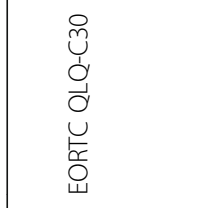 & 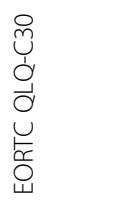 & 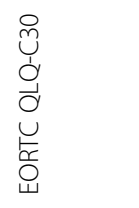 & 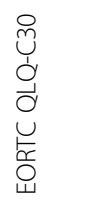 & 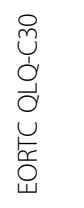 & 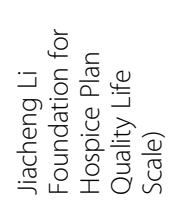 & 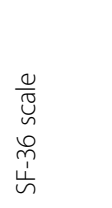 & 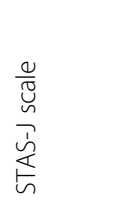 & 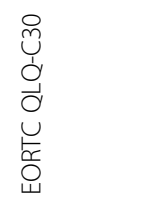 & 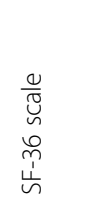 \\
\hline 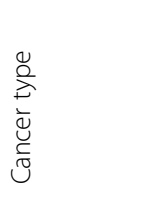 & 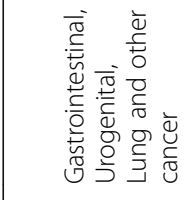 & 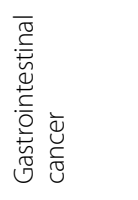 & 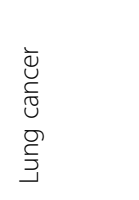 & 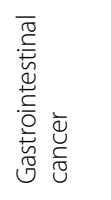 & 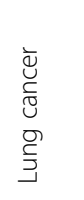 & 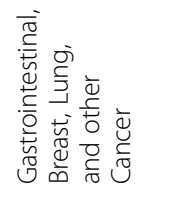 & 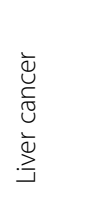 & 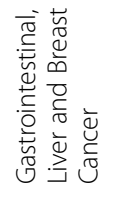 & 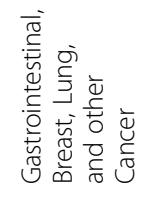 & $\begin{array}{l}\overline{\bar{U}} \\
\overline{\tilde{U}} \\
\stackrel{\bar{\nu}}{\Xi}\end{array}$ \\
\hline 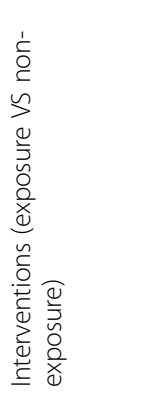 & 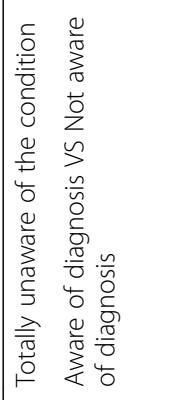 & 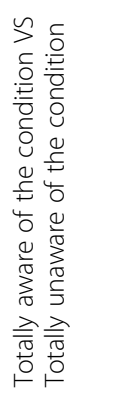 & 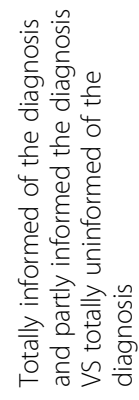 & 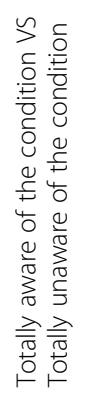 & 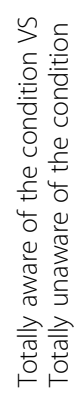 & 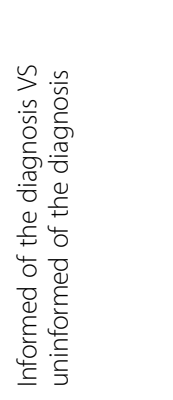 & 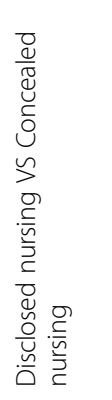 & 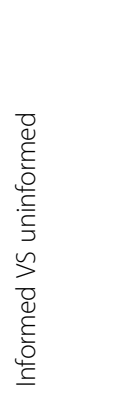 & 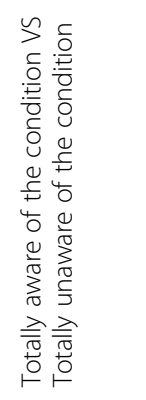 & 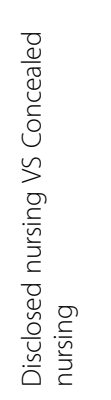 \\
\hline :5 & 늠 & 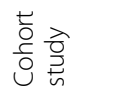 & 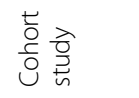 & 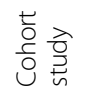 & 蒿 & 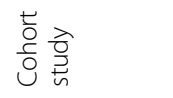 & 늠 & 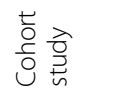 & 蒿 & 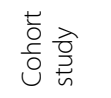 \\
\hline 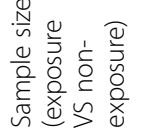 & $\underset{\substack{\infty \\
ٌ}}{\infty}$ & 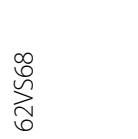 & & 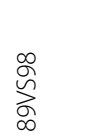 & & 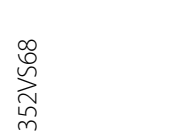 & 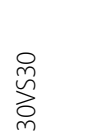 & 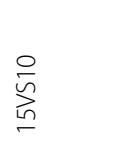 & 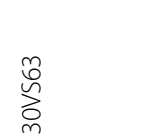 & 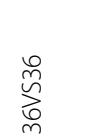 \\
\hline 莺 & 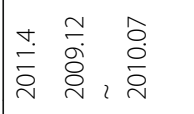 & 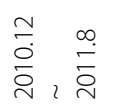 & $\begin{array}{l}\stackrel{0}{\overrightarrow{0}} \\
\stackrel{\overrightarrow{0}}{\overrightarrow{0}},\end{array}$ & 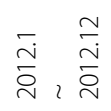 & $\hat{o}^{2} \stackrel{2}{2}$ & 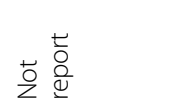 & 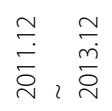 & 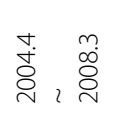 & 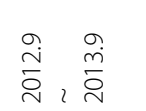 & 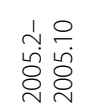 \\
\hline 次 & 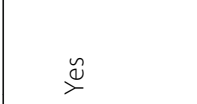 & 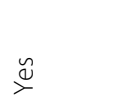 & $2 \stackrel{\frac{\hbar}{0}}{\stackrel{0}{2}}$ & 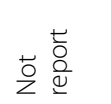 & 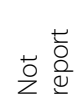 & 苍蒿 & $\frac{\pi}{2} \frac{\underline{0}}{2}$ & $\frac{\vec{t}}{2}$ & 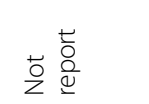 & 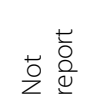 \\
\hline 总 & : & : & : & : & : & $\stackrel{\stackrel{0}{E}}{\frac{E}{U}}$ & $\stackrel{\stackrel{0}{E}}{\frac{E}{U}}$ & $\begin{array}{l}\frac{1}{0} \\
\frac{0}{0} \\
\frac{0}{n}\end{array}$ & : & 导 \\
\hline $\begin{array}{l}\overline{\widetilde{\sigma}} \\
\overline{5}\end{array}$ & 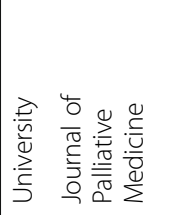 & 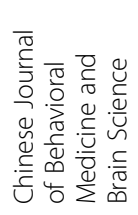 & 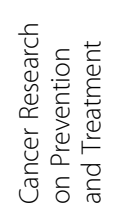 & 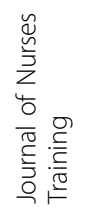 & 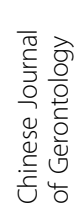 & 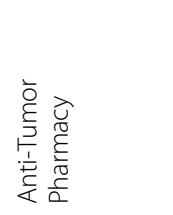 & 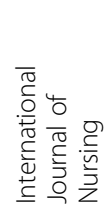 & 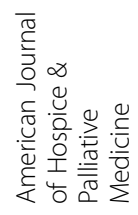 & 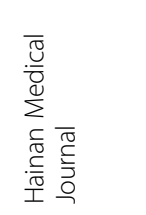 & 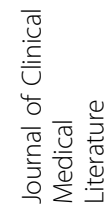 \\
\hline & 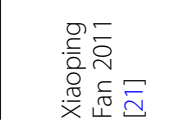 & 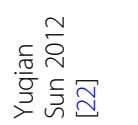 & 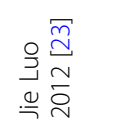 & 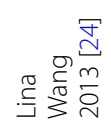 & 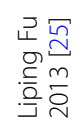 & 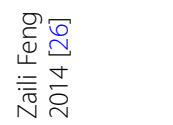 & 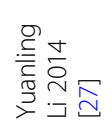 & 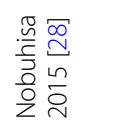 & 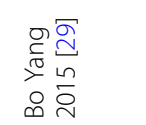 & 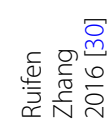 \\
\hline
\end{tabular}


Table 2 Risk of bias summary: review authors' judgements about each risk of bias item for each included study

\begin{tabular}{|c|c|c|c|c|c|c|c|c|}
\hline Study ID & $\begin{array}{l}\text { 1.Bias due to } \\
\text { confounding }\end{array}$ & $\begin{array}{l}\text { 2.Bias in selection of } \\
\text { participants into the } \\
\text { study }\end{array}$ & $\begin{array}{l}\text { 3.Bias in } \\
\text { classification of } \\
\text { interventions }\end{array}$ & $\begin{array}{l}\text { 4.Bias due to } \\
\text { deviations from } \\
\text { intended interventions }\end{array}$ & $\begin{array}{l}\text { 5.Bias due } \\
\text { to missing } \\
\text { data }\end{array}$ & $\begin{array}{l}\text { 6.Bias in } \\
\text { measurement } \\
\text { of outcomes }\end{array}$ & $\begin{array}{l}\text { 7.Bias in } \\
\text { selection of the } \\
\text { reported result }\end{array}$ & $\begin{array}{l}\text { overall } \\
\text { risk of } \\
\text { bias }\end{array}$ \\
\hline $\begin{array}{l}\text { Ali } 2009 \\
\text { [19] }\end{array}$ & $* * *$ & $* * * *$ & $* * * *$ & ***** & $* * * *$ & ***** & $a$ & $* * *$ \\
\hline $\begin{array}{l}\text { Xiaoping } \\
\text { Fan } 2011\end{array}$ & $* * *$ & $* * * *$ & $* * * *$ & $* *$ & $* * *$ & $* * * *$ & a & $* *$ \\
\hline $\begin{array}{l}\text { Yuanling } \\
\text { Li } 2014 \\
{[27]}\end{array}$ & $* * *$ & $* * * *$ & $* * * *$ & $* * * *$ & $* * * *$ & $* * * *$ & a & $* * *$ \\
\hline $\begin{array}{l}\text { Jianjun } \\
\text { Zou } 2006 \\
{[10]}\end{array}$ & $* *$ & $* * * *$ & $* * * *$ & $* * * *$ & $* * * *$ & $* * * *$ & a & $* * *$ \\
\hline $\begin{array}{l}\text { Jie Luo } \\
2012 \text { [23] }\end{array}$ & $* *$ & $* * * *$ & $* * * *$ & $* * * *$ & $* * * *$ & $* * * *$ & a & $* *$ \\
\hline $\begin{array}{l}\text { Zhenjing } \\
\text { Liu 2006 } \\
\text { [11] }\end{array}$ & $* *$ & $* * * *$ & * & $* * * *$ & $* * * *$ & $* * * *$ & a & * \\
\hline $\begin{array}{l}\text { Noritoshi } \\
1998[8]\end{array}$ & $* *$ & $* * * *$ & $* * * *$ & $* * * *$ & $* * *$ & $* * * *$ & $* * * *$ & $* *$ \\
\hline $\begin{array}{l}\text { Nobuhisa } \\
2015 \text { [28] }\end{array}$ & $* *$ & $* * * *$ & $* * * *$ & $* * * *$ & * & $* * * *$ & a & * \\
\hline $\begin{array}{l}\text { Liping } \\
\text { Zhao } 2007 \\
{[14]}\end{array}$ & $* *$ & $* * * *$ & $* * * *$ & $* * * *$ & $* * * *$ & $* * * *$ & a & $* *$ \\
\hline $\begin{array}{l}\text { Lianxue } \\
\text { Zheng } \\
2009 \text { [16] }\end{array}$ & * & $* * * *$ & $* * * *$ & $* * * *$ & $* * * *$ & $* * * *$ & a & $*$ \\
\hline $\begin{array}{l}\text { Ruihong } \\
\text { Kong } 2009 \\
{[17]}\end{array}$ & $*$ & $* * * *$ & $* * * *$ & $* * * *$ & $*$ & $* * * *$ & a & $*$ \\
\hline $\begin{array}{l}\text { Zaili Feng } \\
2014 \text { [26] }\end{array}$ & $* *$ & $* * * *$ & $* * * *$ & $* * * *$ & $* * * *$ & $* * * *$ & a & $* *$ \\
\hline $\begin{array}{l}\text { Xue Xu } \\
2011[20]\end{array}$ & $* * *$ & $* * * *$ & $* * * *$ & $* * * *$ & $* * * *$ & $* * * *$ & a & $* * * *$ \\
\hline $\begin{array}{l}\text { Lina Wang } \\
2013 \text { [24] }\end{array}$ & $* * * *$ & $* * * *$ & $* * * *$ & $* * * *$ & $* * *$ & $* * * *$ & a & $* * *$ \\
\hline $\begin{array}{l}\text { Fang Ding } \\
2008 \text { [15] }\end{array}$ & $* *$ & $* * * *$ & $* * * *$ & $* * * *$ & $* * * *$ & $* * * *$ & a & $* *$ \\
\hline $\begin{array}{l}\text { Zhaoxia Li } \\
2009 \text { [18] }\end{array}$ & $* *$ & $* * * *$ & $* * *$ & $* * * *$ & $* * * *$ & $* * * *$ & a & $* *$ \\
\hline $\begin{array}{l}\text { Bo Yang } \\
2015 \text { [29] }\end{array}$ & $* * * *$ & $* * * *$ & $* * *$ & $* * * *$ & $* * * *$ & $* * * *$ & a & $* * *$ \\
\hline $\begin{array}{l}\text { Yuqian } \\
\text { Sun } 2012 \\
{[22]}\end{array}$ & $* *$ & $* * * *$ & $* * *$ & $* * * *$ & $* * * *$ & $* * * *$ & a & $* *$ \\
\hline $\begin{array}{l}\text { Alexandra } \\
2006 \text { [13] }\end{array}$ & $* * *$ & $* * * *$ & $* * * *$ & $* * * *$ & $* * * *$ & $* * * *$ & a & $* * *$ \\
\hline $\begin{array}{l}\text { H. Bozcuk } \\
2001[9]\end{array}$ & $* * *$ & $* * * *$ & $* * * *$ & $* * * *$ & $* * * *$ & $* * * *$ & a & $* * *$ \\
\hline $\begin{array}{l}\text { Liping Fu } \\
2013 \text { [25] }\end{array}$ & $* *$ & $* * * *$ & $* * *$ & $* * * *$ & $* * * *$ & $* * * *$ & $a$ & $* *$ \\
\hline $\begin{array}{l}\text { Xiuling } \\
\text { Wang } \\
2006 \text { [12] }\end{array}$ & $* *$ & $* * * *$ & $* * * *$ & $* *$ & $* * * *$ & $* * * *$ & a & $* *$ \\
\hline $\begin{array}{l}\text { Ruifen } \\
\text { Zhang } \\
2016 \text { [30] }\end{array}$ & $* *$ & $* * * *$ & $* * * *$ & $* *$ & $* * * *$ & $* * * *$ & $\mathrm{a}$ & $* *$ \\
\hline
\end{tabular}




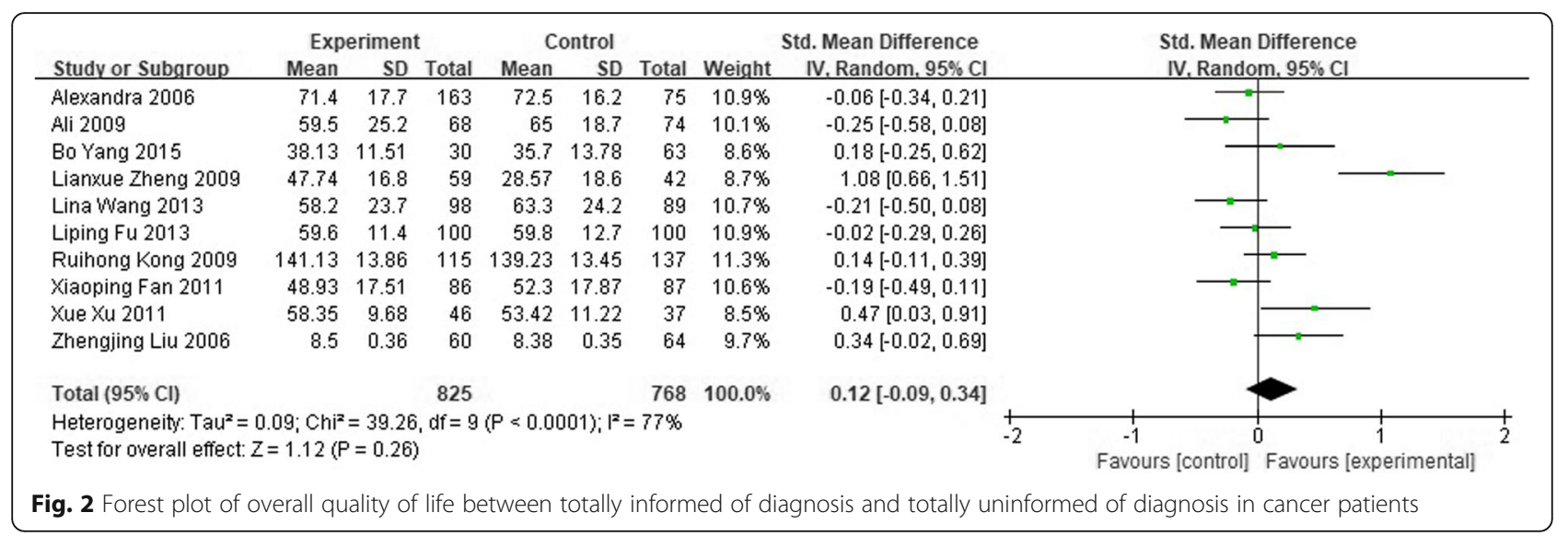

\section{Primary and secondary outcome measures}

The included studies used self-reported participant measures of QoL as primary or secondary end points.

\section{Primary outcomes}

General quality of life;

\section{Secondary outcomes}

1) QoL domains:

i. physical capability (e.g. ability to perform selfcare activities, mobility, and physical activities);

ii. social capability (e.g. ability to perform work or household responsibilities and social interactions);

iii. role function (e.g. ability to perform in daily life, amusement, and hobbies);

iv. emotional wellbeing (e.g. levels of sadness, anxiety, depression, and/or negative affects);

v. cognitive capacity (e.g. ability to focus attention and form/retain memories);

vi. vitality (e.g. overall energy and fatigue);

vii. economic ability (e.g. financial difficulty)

2) Disease-related symptoms (or both), including fatigue, pain, dyspnea, insomnia, appetite loss, and/ or diarrhea.

\section{Assessment of risk of bias in included studies}

Pairs of reviewers independently assessed risk of bias in the included studies by using the ROBINS-I assessment tool [7] for non-randomized studies, and the Cochrane risk of bias tool for randomized controlled trials. Any disagreements were resolved by discussion or consulting the third reviewer.

\section{Assessment of publication bias}

If we included at least 10 studies in a meta-analysis, we generated funnel plots of effect estimates against their standard errors (on a reversed scale) using Review Manager software (RevMan). We assessed the potential risk of publication bias through a visual analysis of the funnel plots. Roughly symmetrical funnel plots indicated a low risk of publication bias and asymmetrical funnel plots a high risk. One should be aware that this is a rather subjective judgement and that funnel plot asymmetry might also arise from other sources and that publication bias does not always lead to asymmetry. We further attempted to avoid publication bias by searching trials registries and conference proceedings for unpublished studies. We addressed duplicate publication bias by including only one study with more than one publication. If we had doubt about whether multiple publications referred to the same data, we attempted to contact trial authors by email to resolve this issue.

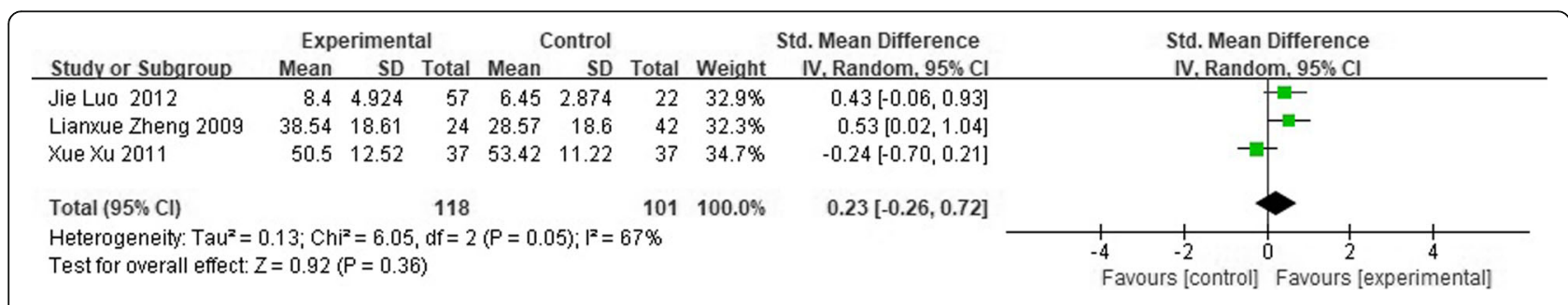

Fig. 3 Forest plot of overall quality of life between partly informed of diagnosis and totally uninformed of diagnosis in cancer patients 
Table 3 Overall Meta-analysis summary between Totally informed of diagnosis and Uninformed of diagnosis in cancer patients

\begin{tabular}{llll}
\hline Outcome or subgroup & Participants & Std. Mean Difference (IV, Random, 95\% Cl) & $P$ value \\
\hline General Quality of Life & 1593 & $0.12[-0.09,0.34]$ & \\
Function domains & & 0.26 \\
$\quad$ Role Function & 1250 & $0.17[-0.05,0.39]$ & 0.13 \\
Cognitive Activity & 1150 & $2.22[0.11,4.33]$ \\
Vitality & 212 & $0.06,1.28]$ & 0.08 \\
Emotional Function & 1793 & $0.58[0.11,1.05]$ \\
Social Function & 2045 & $0.03[-0.26,0.32$ \\
Physical Function & 1733 & & 0.04 \\
Disease-related symptoms & & $-0.13[-0.46,0.20]$ \\
Nausea and Vomiting & 1250 & $-0.24[-0.61,0.14]$ \\
Pain & 1541 & $-0.01[-0.12,0.10]$ \\
Dyspnea & 1250 & $0.07[-0.23,0.38]$ \\
Fatigue & 1250 & $-0.03[-0.21,0.15]$ \\
Diarrhea & 1250 & $0.04[-0.12,0.20]$ \\
Constipation & 1250 & $0.06[-0.05,0.17]$ \\
Appetite Loss & 1250 & $0.08[-0.05,0.21]$ \\
Insomnia & 1250 & & 0.02 \\
\hline & & 0.83 \\
\hline
\end{tabular}

\section{Grading of the evidence quality}

Based on the results of the systematic review, the GRADE system was applied to evaluate the quality of the evidence, with results divided as follows: High quality (or A) - very confident that the real effect value is close to the estimated effect value, Moderate quality (or B) - having a moderate degree of confidence in the estimated value of the effect, and while the real value may be close to the estimated value there is still the possibility of large difference between the two groups, Low quality (or C) - limited confidence in the effect estimate and the true value may be quite different from the estimate, and Very low quality (or D) - little confidence in the effect estimate, with the true value likely to be very different from the estimate. Although evidence based on randomized controlled trails (RCT) is initially classified as high quality, confidence in such evidence may be diminished by five factors: (1) study limitations, (2) inconsistency in research results, (3) use of indirect evidence, (4) inaccurate results, and (5) publication bias. Evidence can be upgraded based on the following three factors; (1) large effect value, (2) existence of a dose-effect

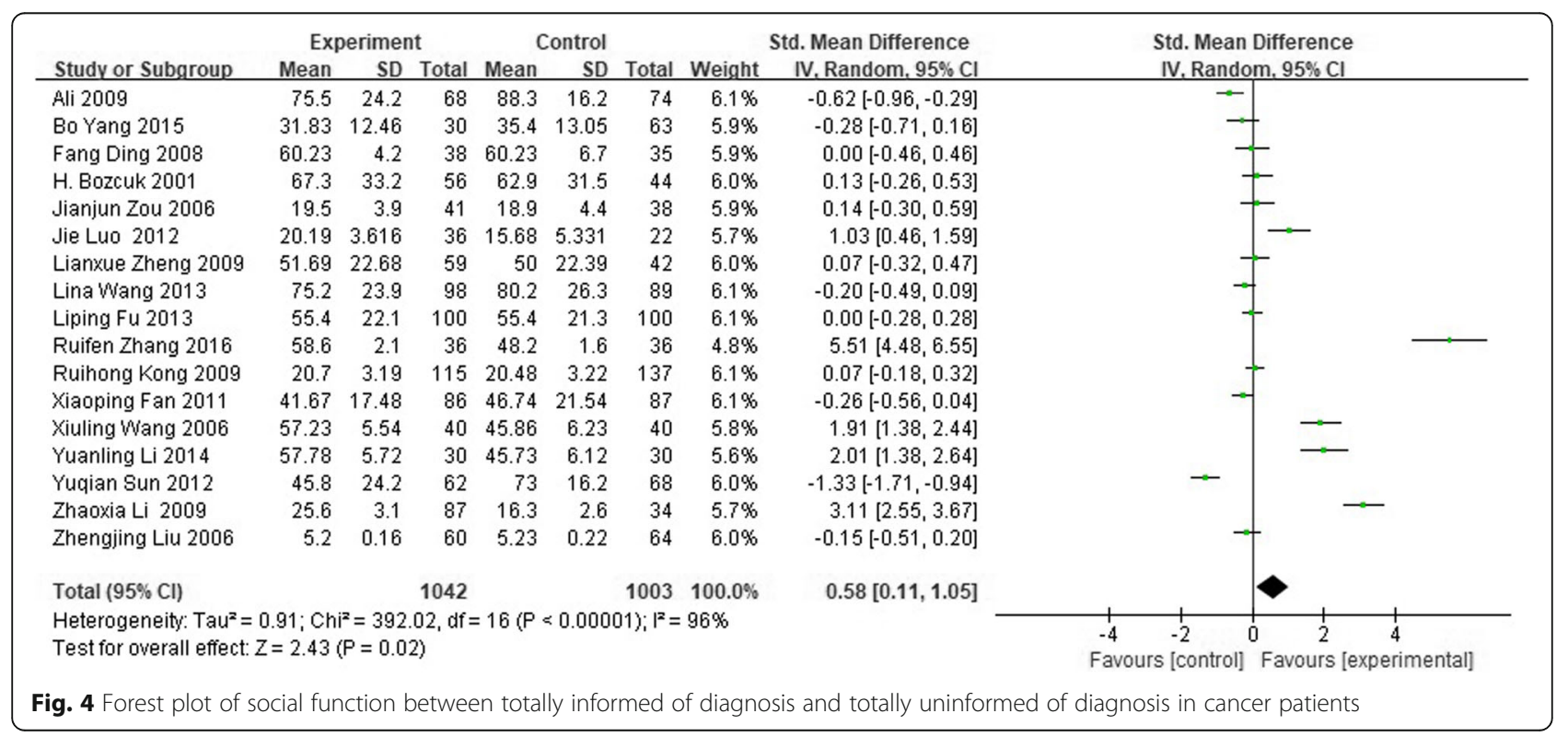




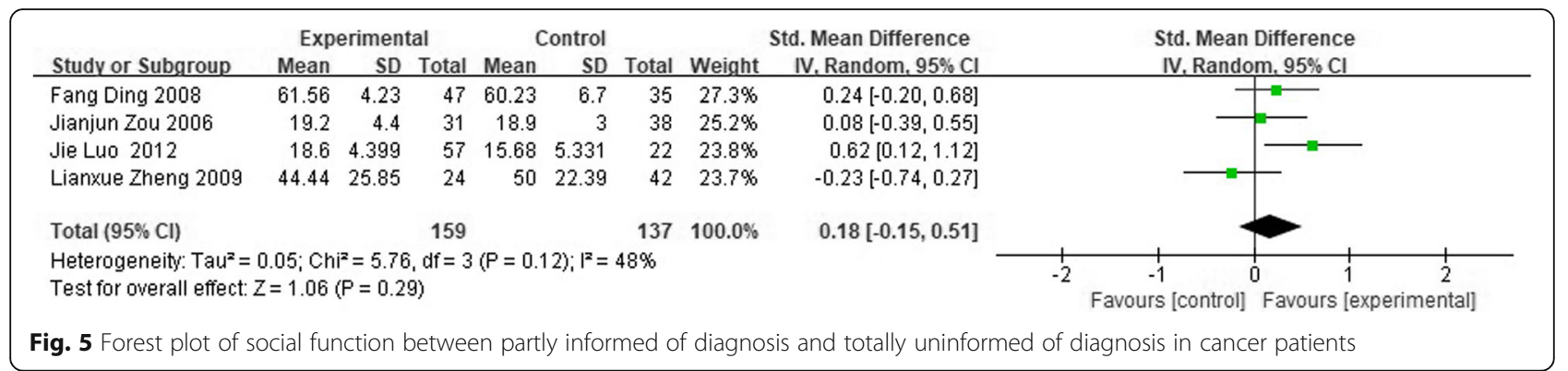

relationship, and (3) a possible confounding bias which may reduce efficacy.

\section{Data synthesis strategy}

Measures of treatment effect: We analyzed continuous outcomes as standardized mean differences (SMD) between groups with 95\% CIs. To assess heterogeneity, we determined statistical heterogeneity using the 2 test. If heterogeneity was low ( $\mathrm{I} 2<50 \%, \mathrm{P}>0.05$ ), we used the fixed effects model to calculate the combined effect. If heterogeneity was high ( $2 \geq 50 \%, P \leq 0$. 05), we used the random effects model to combine the studies. To assess reporting biases, we investigated publication and other reporting biases using funnel plots.

\section{Results}

\section{Literature search}

Following a comprehensive literature search, we identified and screened 11,740 references. Eleven thousand six hundred eight references were excluded based on the title and abstract. After screening the full text, a further 108 references were excluded. Following exclusions, a total of 23 references were included for further analysis. A flowchart of the search process is shown in Fig. 1.

\section{Overall study characteristics}

The 23 included studies were all cohort studies. In all, 3322 (range 10 to 352 ) participants were enrolled. Detailed information on overall study characteristics are shown in Table 1.

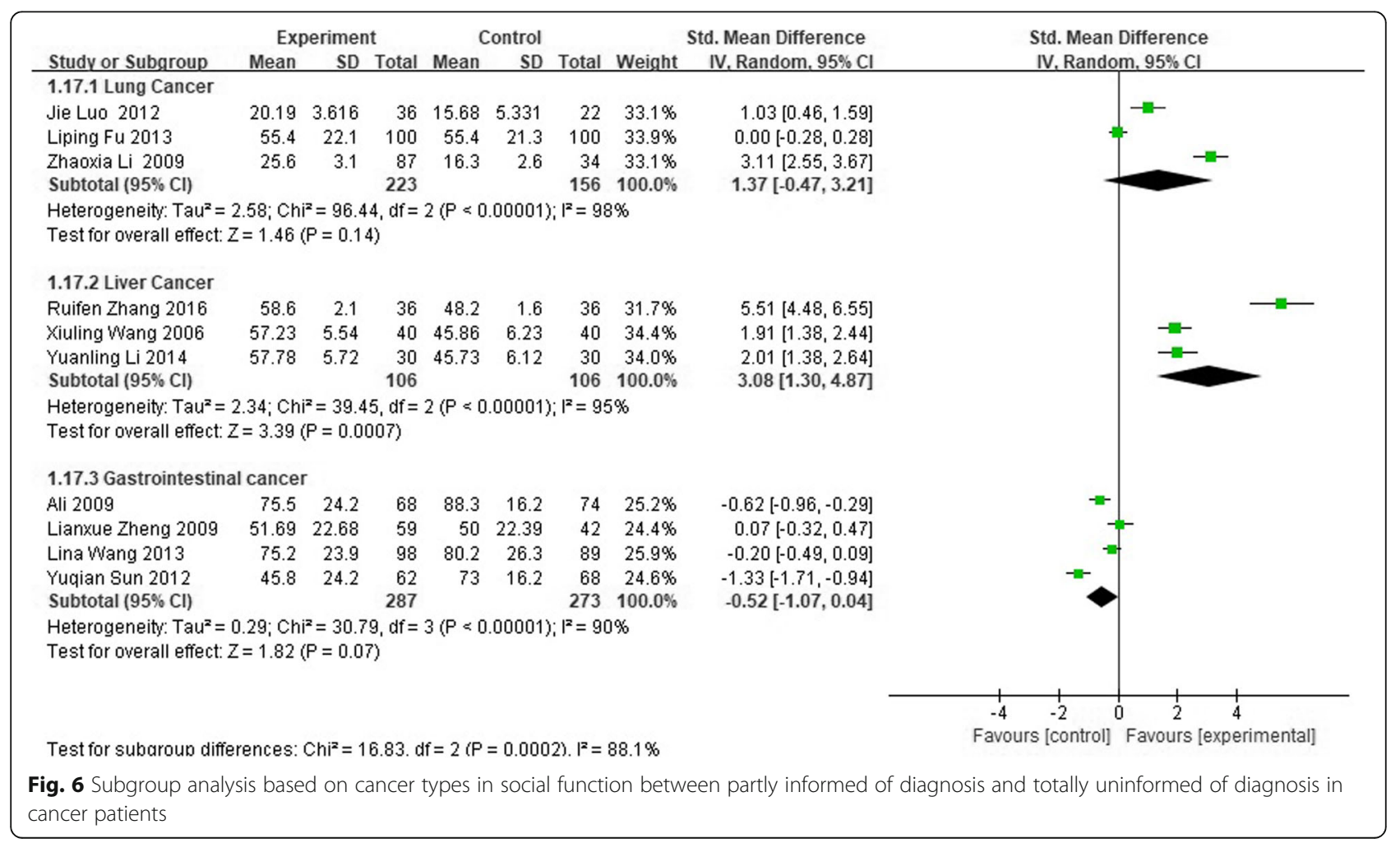




\begin{tabular}{|c|c|c|c|c|c|c|c|c|c|c|c|}
\hline \multirow[b]{2}{*}{ Study or Subgroup } & \multicolumn{3}{|c|}{ Experiment } & \multicolumn{2}{|c|}{ Control } & \multirow[b]{2}{*}{ Total } & \multirow[b]{2}{*}{ Weight } & \multirow{2}{*}{$\begin{array}{l}\text { Std. Mean Difference } \\
\quad \text { IV. Random, } 95 \% \mathrm{Cl}\end{array}$} & \multirow{2}{*}{\multicolumn{2}{|c|}{$\begin{array}{l}\text { Std. Mean Difference } \\
\text { IV. Random, } 95 \% \mathrm{Cl}\end{array}$}} & \multirow[b]{3}{*}{-를- } \\
\hline & Mean & SD & Total & Mean & SD & & & & & & \\
\hline Ruifen Zhang 2016 & 54.6 & 2.5 & 36 & 45.2 & 1.3 & 36 & $32.4 \%$ & $4.67[3.76,5.58]$ & & \multirow{3}{*}{-} & \\
\hline Xiuling Wang 2006 & 51.94 & 5.34 & 40 & 49.96 & 4.32 & 40 & $34.0 \%$ & $0.40[-0.04,0.85]$ & & & \\
\hline Yuanling Li 2014 & 51.9 & 5.43 & 30 & 43.56 & 4.23 & 30 & $33.6 \%$ & $1.69[1.10,2.29]$ & & & \\
\hline Total $(95 \% \mathrm{Cl})$ & & & 106 & & & 106 & $100.0 \%$ & $2.22[0.11,4.33]$ & & & \\
\hline \multicolumn{8}{|c|}{$\begin{array}{l}\text { Heterogeneity: } \text { Tau }^{2}=3.36 ; \mathrm{Chi}^{2}=69.83, \mathrm{df}=2(\mathrm{P}<0.00001) ; \mathrm{I}^{2}=97 \% \\
\text { Test for overall effect: } Z=2.06(\mathrm{P}=0.04)\end{array}$} & & $\begin{array}{ccc}-4 & -2 & 1 \\
\text { Favours [control] }\end{array}$ & $\begin{array}{cc}0 & 2 \\
\text { Favours [ex }\end{array}$ & $\begin{array}{l}4 \\
\text { periments }\end{array}$ \\
\hline
\end{tabular}

\section{Risk of bias in included studies}

Included studies were assessed for risk of bias using the ROBINS-I assessment tool. For each trial the risk of bias is detailed in Table 2.

\section{Meta-analysis results \\ Overall quality of life}

There was no difference in the change in QoL from baseline between totally informed and uninformed of diagnosis in 1593 study patients (SMD 0.12; 95\% CI-0.09 to 0.34 ), and no difference between partly informed and uninformed of diagnosis in 219 participants (SMD 0.23; 95\% CI-0.26 to 0.72). Details shown in Figs. 2 and 3.

\section{Role function}

Meta-analyses comparing totally informed with control intervention showed no differences in role function among 1250 patients. The same result was seen with patients partly informed of diagnosis. See Table 3 for detailed information.

\section{Cognitive activity}

We found no significant effect on cognitive activity from totally informing cancer patients of diagnosis. See Table 3 for detailed information.

\section{Physical function}

No difference in scores was observed between totally informed and uninformed of diagnosis groups in 1150 cancer patients. See Table 3 for detailed information.

\section{Social function}

Compared to patients uninformed of diagnosis, totally informed patients did better, and their social function was significantly affected among 2130 cancer patients (SMD 0.63; 95\% CI 0.18 to 1.09). Subgroup analysis based on cancer types showed that there was no difference in lung and gastrointestinal cancer patients $(P>$ $0.05)$, while in liver cancer, patients totally informed of diagnosis did better than uninformed patients (SMD 3.08; $95 \%$ CI 1.30 to 4.87 ). No difference was seen between the partly and totally uninformed of diagnosis groups (SMD 0.18; 95\% CI -0.15 to 0.51 ) in 296 patients. See Figs. 4, 5 and 6 for forest picture.

\section{Vitality}

Totally informed were significantly better than uninformed of diagnosis in role function among 212 cancer patients (SMD 2.22; 95\%CI 0.11 to 4.33). No information on partly informed versus totally uninformed patients was found for use in this study. More information is shown in Fig. 7.

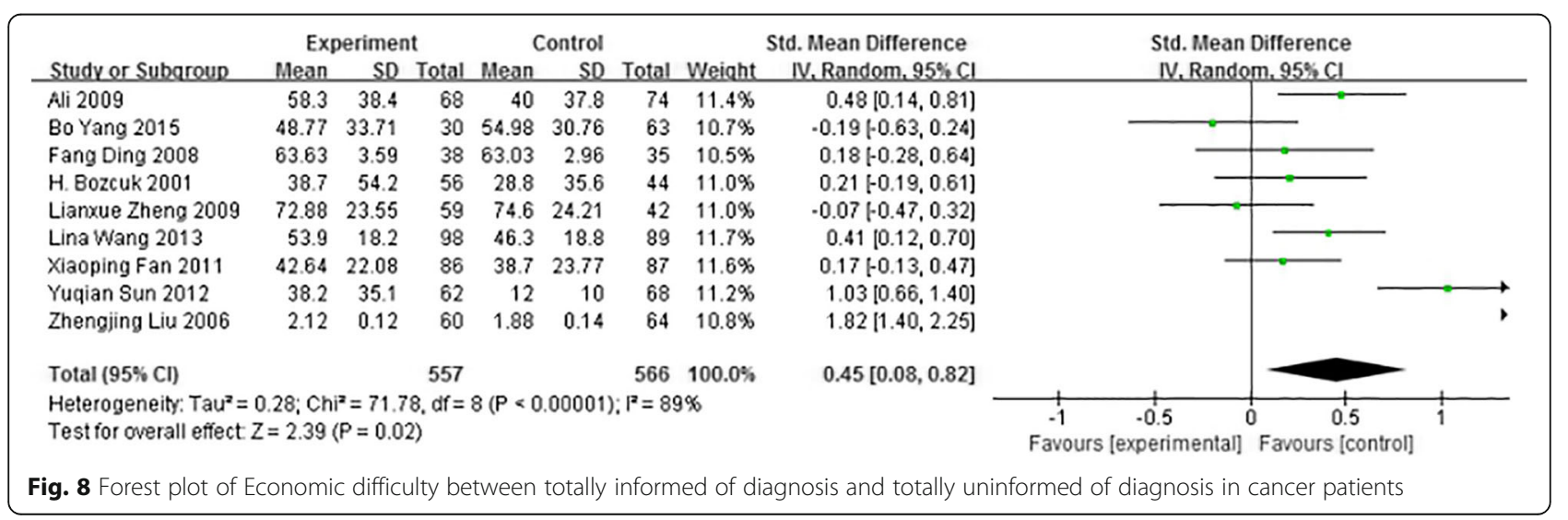




\section{Emotional function}

No difference was seen between the totally and partly informed diagnosis groups compared to totally uninformed groups. See Table 3 for detailed information.

\section{Economic difficulty}

We observed that in terms of economic function, totally informed performed significantly worse than uninformed of diagnosis groups in 1123 participants when looking at the change in scores across instruments from baseline to follow-up (SMD 0.45; 95\%CI 0.08 to 0.82). Totally informed of diagnosis patients more often felt economic difficulty than those uninformed of diagnosis. See Fig. 8 for detailed information.

\section{Disease-related symptoms}

We observed no significant effect between totally informed and uninformed of diagnosis groups in assessments of fatigue, pain, dyspnea, diarrhea, constipation, appetite loss, insomnia, nausea, and vomiting. Details shown in Tables 3 and 4.

\section{Grading of evidence quality}

Results based on systematic reviews were graded low and very low. Details in Table 5.

\section{Publication bias}

Because we included 10 studies in the meta-analysis of overall quality of life between totally informed and totally uninformed of diagnosis cancer patients, we generated a funnel plot of effect estimates against their standard errors (on a reversed scale) using Review Manager software (RevMan). The funnel plot was nearly symmetrical and every meta-analysis exited negative and positive results, which meant that there is little possibility of publication bias in this study. See Fig. 9 for detailed information.

\section{Discussion}

\section{Summary of main results}

We included 23 trials with 3322 participants distributed over totally informed, partly informed, and uninformed

Table 4 Overall Meta-analysis summary between partly informed of diagnosis and totally uninformed of diagnosis in cancer patients

\begin{tabular}{lccc}
\hline General Quality of Life & 219 & $0.23[-0.26,0.72]$ & 0.36 \\
\hline Function domains & & & \\
Physical Function & 286 & $0.01[-0.22,0.25]$ & 0.93 \\
Social Function & 296 & $0.18[-0.15,0.51]$ & 0.29 \\
Emotional Function & 296 & $-1.24[-2.75,0.26]$ & 0.11 \\
Disease-related symptoms & & & \\
Pain & 217 & $-0.15[-0.42,0.13]$ & 0.30 \\
\hline
\end{tabular}

of diagnosis groups. Conference abstracts and studies whose full text was unavailable were excluded. Almost all the included studies were of low quality, among which 20 studies had an existing bias due to various confounding factors such as age and degree of education, and only 5 had an adjusting analysis. The 3 other studies were bias-free due to the consistency of their confoundings and baselines. Results based on systematic reviews were graded low and very low. The main reasons for their downgrading were that the confidence interval overlaps were low and $\mathrm{I}^{2}$ was larger than $50 \%$, sample sizes had fewer than 300 participants included in the total, and the $95 \%$ confidence interval was too wide.

Through meta-analysis, cancer patients who were totally informed or uninformed of the diagnosis had no differences in either their general quality of life and symptoms of fatigue, pain, dyspnea, insomnia, appetite loss, and diarrhea $(P>0.05)$. There was also no difference in the physical function, role function, cognitive activity, and emotional function, of the groups $(P>0.05)$. However, in terms of vitality and social function, totally informed patients did better than uninformed patients. Subgroup analysis based on cancer types showed that liver cancer patients who were totally informed of their diagnosis did better than those uninformed in social function, but informed patients seemed to get higher scores in financial difficulty. Between the partly informed and uninformed groups, no differences were found in general quality of life, function domains, and disease-related symptoms $(\mathrm{P}>0.05)$.

\section{Implications for practice}

Cancer is a special concern around the world and a patients' quality of life is an important aspect in their therapeutic journey [31-34]. The issue of whether cancer patients should be informed of their diagnosis has long been debated [35]. Some people contend that telling the truth to them and their relatives upholds their right to know, while others would say that white lies can ease worries and help patients' psychological defense $[9,19,22,25$, 35]. Our results showed that there is no significant impact on health-related quality of life in cancer patients between the patient being fully informed, partially informed, or completely uninformed of their cancer diagnosis. This indicates that physicians could inform patients and educate them, which would help them understand their cancer and get the families, patients, and doctors in charge together to make personalized and systematic therapy plans and accurately evaluate prognosis [8]. Concealing the truth might render patients' suspicious and gloomy, potentially leading to depression that could promote tumor progression. When exposing patients to the truth, it would be better for the clinicians to educate patients and their families separately. This is because patients need more knowledge about the cancer to fight against it bravely and optimistically, 
Table 5 Summary of findings for the main comparison

\begin{tabular}{|c|c|c|c|c|}
\hline \multicolumn{5}{|c|}{ Totally informed of diagnosis versus uninformed of diagnosis } \\
\hline \multicolumn{5}{|c|}{ Patient: cancer patients } \\
\hline \multicolumn{5}{|c|}{ Intervention: totally informed of diagnosis } \\
\hline \multicolumn{5}{|c|}{ Comparison: uninformed of diagnosis } \\
\hline Outcomes & $\begin{array}{l}\text { Sample Size } \\
\text { (Number + } \\
\text { Study } \\
\text { Design) }\end{array}$ & $\begin{array}{l}\text { Evidence } \\
\text { Grade }\end{array}$ & $\begin{array}{l}\text { Relative } \\
\text { Effect } \\
(95 \% \text { Cl) }\end{array}$ & $\begin{array}{l}\text { Prospective } \\
\text { Absolute Effect } \\
(95 \% \mathrm{Cl})\end{array}$ \\
\hline $\begin{array}{l}\text { General } \\
\text { Quality of } \\
\text { Life }\end{array}$ & $\begin{array}{l}1593 \text { (10 } \\
\text { cohort } \\
\text { studies) }\end{array}$ & $\begin{array}{l}\text { Very } \\
\text { Low }^{1} \oplus \circ \circ \circ\end{array}$ & $\begin{array}{l}\text { SMD } \\
0.12[- \\
0.09 \\
0.34]\end{array}$ & $\begin{array}{l}\text { SMD } 0.12 \text { SD } \\
\text { higher }(-0.09 \\
\text { lower to } 0.34 \\
\text { higher) }\end{array}$ \\
\hline $\begin{array}{l}\text { Role } \\
\text { Functioning }\end{array}$ & $\begin{array}{l}1250 \text { (9 } \\
\text { cohort } \\
\text { studies) }\end{array}$ & Low $\oplus \oplus \circ \circ$ & $\begin{array}{l}\text { MD } 0.17 \\
{[-0.05} \\
0.39]\end{array}$ & $\begin{array}{l}\text { MD } 0.17 \text { higher } \\
\text { (- } 0.05 \text { lower to } \\
0.39 \text { higher })\end{array}$ \\
\hline $\begin{array}{l}\text { Cognitive } \\
\text { Activity }\end{array}$ & $\begin{array}{l}1150(8 \\
\text { cohort } \\
\text { studies) }\end{array}$ & $\begin{array}{l}\text { Very } \\
\text { Low }^{2} \oplus \circ \circ \circ\end{array}$ & $\begin{array}{l}\text { SMD } \\
0.61[- \\
0.06 \\
1.28]\end{array}$ & $\begin{array}{l}\text { SMD } 0.61 \text { higher } \\
\text { (- } 0.06 \text { lower to } \\
1.28 \text { higher) }\end{array}$ \\
\hline Vitality & $\begin{array}{l}212 \text { (3 } \\
\text { cohort } \\
\text { studies) }\end{array}$ & $\begin{array}{l}\text { Very Low }{ }^{23} \\
{ }^{4} \oplus \circ 00\end{array}$ & $\begin{array}{l}\text { SMD } \\
2.22 \\
{[0.11} \\
4.33]\end{array}$ & $\begin{array}{l}\text { SMD } 2.22 \text { higher } \\
\text { ( } 0.11 \text { lower to } \\
4.33 \text { higher) }\end{array}$ \\
\hline $\begin{array}{l}\text { Emotional } \\
\text { Function }\end{array}$ & $\begin{array}{l}1793 \text { (14 } \\
\text { cohort } \\
\text { studies) }\end{array}$ & $\begin{array}{l}\text { Very Low } \\
{ }^{5} \oplus \circ 0 \circ\end{array}$ & $\begin{array}{l}\text { SMD } \\
0.13 \\
{[-0.20} \\
0.47]\end{array}$ & $\begin{array}{l}\text { SMD } 0.13 \text { higher } \\
(-0.20 \text { lower to } \\
0.47 \text { higher })\end{array}$ \\
\hline $\begin{array}{l}\text { Social } \\
\text { Function }\end{array}$ & $\begin{array}{l}2045 \text { (17 } \\
\text { cohort } \\
\text { studies) }\end{array}$ & $\begin{array}{l}\text { Very Low } \\
{ }^{6} \oplus \circ 00\end{array}$ & $\begin{array}{l}\text { SMD } \\
0.58 \\
{[0.11} \\
1.05]\end{array}$ & $\begin{array}{l}\text { SMD } 0.58 \text { higher } \\
\text { (0.11 lower to } \\
1.05 \text { higher) }\end{array}$ \\
\hline $\begin{array}{l}\text { Physical } \\
\text { Function }\end{array}$ & $\begin{array}{l}1733(13 \\
\text { cohort } \\
\text { studies) }\end{array}$ & $\begin{array}{l}\text { Low } \\
{ }^{7} \oplus \oplus \circ \circ\end{array}$ & $\begin{array}{l}\text { SMD } \\
0.03 \\
{[-0.26} \\
0.32]\end{array}$ & $\begin{array}{l}\text { SMD } 0.03 \text { higher } \\
\text { (- } 0.26 \text { lower to } \\
0.32 \text { higher) }\end{array}$ \\
\hline $\begin{array}{l}\text { Nausea and } \\
\text { Vomiting }\end{array}$ & $\begin{array}{l}1250(9 \\
\text { cohort } \\
\text { studies) }\end{array}$ & $\begin{array}{l}\text { Very Low } \\
{ }^{8} \oplus \circ \circ \circ\end{array}$ & $\begin{array}{l}\text { SMD - } \\
0.13[- \\
0.46 \\
0.20]\end{array}$ & $\begin{array}{l}\text { SMD }-0.13 \\
\text { higher }(-0.46 \\
\text { lower to } 0.20 \\
\text { higher) }\end{array}$ \\
\hline Pain & $\begin{array}{l}1541 \text { (13 } \\
\text { cohort } \\
\text { studies) }\end{array}$ & $\begin{array}{l}\text { Very } \\
\text { Low }^{9} \oplus \circ \circ \circ\end{array}$ & $\begin{array}{l}\text { SMD - } \\
0.24[- \\
0.61 \\
0.14]\end{array}$ & $\begin{array}{l}\text { SMD }-0.24 \\
\text { higher }(-0.61 \\
\text { lower to } 0.14 \\
\text { higher) }\end{array}$ \\
\hline Dyspnea & $\begin{array}{l}1250 \text { (9 } \\
\text { cohort } \\
\text { studies) }\end{array}$ & Low $\oplus \oplus \circ \circ$ & $\begin{array}{l}\text { SMD - } \\
0.01[- \\
0.12 \\
0.10]\end{array}$ & $\begin{array}{l}\text { SMD }-0.01 \\
\text { higher }(-0.12 \\
\text { lower to } 0.10 \\
\text { higher) }\end{array}$ \\
\hline Fatigue & $\begin{array}{l}1250 \text { (9 } \\
\text { cohort } \\
\text { studies) }\end{array}$ & $\begin{array}{l}\text { Very } \\
\text { Low }^{10} \oplus \circ 00\end{array}$ & $\begin{array}{l}\text { SMD } \\
0.07[- \\
0.23 \\
0.38]\end{array}$ & $\begin{array}{l}\text { SMD } 0.07 \text { higher } \\
\text { (- } 0.23 \text { lower to } \\
0.38 \text { higher })\end{array}$ \\
\hline $\begin{array}{l}\text { Financial } \\
\text { Difficulty }\end{array}$ & $\begin{array}{l}1123 \text { (9 } \\
\text { cohort } \\
\text { studies) }\end{array}$ & $\begin{array}{l}\text { Very } \\
\text { Low }^{8} \oplus \circ \circ \circ\end{array}$ & $\begin{array}{l}\text { SMD } \\
0.14 \\
(0.01 \sim \\
1.47)\end{array}$ & $\begin{array}{l}\text { SMD } 0.14 \text { higher } \\
\text { (0.01 lower to } \\
1.47 \text { higher) }\end{array}$ \\
\hline Diarrhea & $\begin{array}{l}1250 \text { (9 } \\
\text { cohort } \\
\text { studies) }\end{array}$ & $\begin{array}{l}\text { Very } \\
\text { Low }^{11} \oplus \circ \circ \circ\end{array}$ & $\begin{array}{l}\text { SMD - } \\
0.03[- \\
0.21 \\
0.15]\end{array}$ & $\begin{array}{l}\text { SMD }-0.03 \\
\text { higher }(-0.21 \\
\text { lower to } 0.15 \\
\text { higher) }\end{array}$ \\
\hline
\end{tabular}

Table 5 Summary of findings for the main comparison (Continued)

\begin{tabular}{|c|c|c|c|c|}
\hline & $\begin{array}{l}\text { cohort } \\
\text { studies) }\end{array}$ & & $\begin{array}{l}0.04[- \\
0.12 \\
0.20]\end{array}$ & $\begin{array}{l}\text { (- } 0.12 \text { lower to } \\
0.20 \text { higher) }\end{array}$ \\
\hline $\begin{array}{l}\text { Appetite } \\
\text { Loss }\end{array}$ & $\begin{array}{l}1250 \text { ( } 9 \\
\text { cohort } \\
\text { studies) }\end{array}$ & Low $\oplus \oplus \circ \circ$ & $\begin{array}{l}\text { SMD } \\
0.06[- \\
0.05 \\
0.17]\end{array}$ & $\begin{array}{l}\text { SMD } 0.06 \text { higher } \\
\text { (-0.05 lower to } \\
0.17 \text { higher })\end{array}$ \\
\hline Insomnia & $\begin{array}{l}1250 \text { ( } 9 \\
\text { cohort } \\
\text { studies) }\end{array}$ & Low $\oplus \oplus \circ \circ$ & $\begin{array}{l}\text { SMD } \\
0.08[- \\
0.05 \\
0.21]\end{array}$ & $\begin{array}{l}\text { SMD } 0.06 \text { higher } \\
\text { (-0.05 lower to } \\
0.17 \text { higher })\end{array}$ \\
\hline
\end{tabular}

Partly informed of diagnosis versus uninformed of diagnosis

Patient: cancer patients

Intervention: partly informed of diagnosis

Comparison: uninformed of diagnosis

\begin{tabular}{|c|c|c|c|c|}
\hline $\begin{array}{l}\text { General } \\
\text { Quality of } \\
\text { Life }\end{array}$ & $\begin{array}{l}219 \text { (3 } \\
\text { cohort } \\
\text { studies) }\end{array}$ & $\begin{array}{l}\text { Very } \\
\text { Low }^{12} \oplus \circ \circ \circ\end{array}$ & $\begin{array}{l}\text { SMD } \\
0.23[- \\
0.26 \\
0.72]\end{array}$ & $\begin{array}{l}\text { SMD } 0.23 \text { higher } \\
\text { ( }-0.26 \text { lower to } \\
0.72 \text { higher) }\end{array}$ \\
\hline Pain & $\begin{array}{l}217(3 \\
\text { cohort } \\
\text { studies) }\end{array}$ & $\begin{array}{l}\text { Very Low }{ }^{3} \\
{ }^{4} \oplus 000\end{array}$ & $\begin{array}{l}\text { SMD - } \\
0.15[- \\
0.42 \\
0.13]\end{array}$ & $\begin{array}{l}\text { MD }-0.15 \\
\text { higher }(-0.42 \\
\text { lower to } 0.13 \\
\text { higher) }\end{array}$ \\
\hline $\begin{array}{l}\text { Physical } \\
\text { Function }\end{array}$ & $\begin{array}{l}286 \text { (4 } \\
\text { cohort } \\
\text { studies) }\end{array}$ & $\begin{array}{l}\text { Very Low }{ }^{3} \\
{ }^{4} \oplus 000\end{array}$ & $\begin{array}{l}\text { SMD } \\
0.01[- \\
0.22 \\
0.25]\end{array}$ & $\begin{array}{l}\text { SMD } 0.01 \text { higher } \\
\text { ( }-0.22 \text { lower to } \\
0.25 \text { higher) }\end{array}$ \\
\hline $\begin{array}{l}\text { Social } \\
\text { Function }\end{array}$ & $\begin{array}{l}296 \text { (4 } \\
\text { cohort } \\
\text { studies) }\end{array}$ & $\begin{array}{l}\text { Very Low }{ }^{3} \\
{ }^{4} \oplus \circ 0 \circ\end{array}$ & $\begin{array}{l}\text { SMD } \\
0.18[- \\
0.15 \\
0.51]\end{array}$ & $\begin{array}{l}\text { SMD } 0.18 \text { higher } \\
\text { (-0.15 lower to } \\
0.51 \text { higher) }\end{array}$ \\
\hline $\begin{array}{l}\text { Emotional } \\
\text { Function }\end{array}$ & $\begin{array}{l}296 \text { (4 } \\
\text { cohort } \\
\text { studies) }\end{array}$ & $\begin{array}{l}\text { Very Low }{ }^{3} \\
{ }^{4} \oplus \circ 0 \circ\end{array}$ & $\begin{array}{l}\text { SMD - } \\
1.24[- \\
2.75 \\
0.26]\end{array}$ & $\begin{array}{l}\text { SMD }-1.24 \\
\text { higher }(-2.75 \\
\text { lower to } 0.26 \\
\text { higher) }\end{array}$ \\
\hline
\end{tabular}

Cl Confidence interval, SMD Standardized mean difference GRADE Working Group grades of evidence

High quality: Further research is very unlikely to change our confidence in the estimate of effect

Moderate quality: Further research is likely to have an important impact on our confidence in the estimate of effect and may change the estimate Low quality: Further research is very likely to have an important impact on our confidence in the estimate of effect and is likely to change the estimate Very low quality: We are very uncertain about the estimate Reasons for downgraded:

1. The confidence interval' overlaps were low and $\mathrm{I}^{2}$ was $70 \%$

2. The confidence interval' overlaps were low and $\mathrm{I}^{2}$ was $97 \%$

3. The sample sizes were fewer than 300 participants included in the total

4. The $95 \%$ confidence interval was too wide

5. The confidence interval' overlaps were low and $\mathrm{I}^{2}$ was $91 \%$

6. The confidence interval' overlaps were low and $\mathrm{I}^{2}$ was $96 \%$

7. The confidence interval' overlaps were low and $\mathrm{I}^{2}$ was $88 \%$

8. The confidence interval' overlaps were low and $\mathrm{I}^{2}$ was $89 \%$

9. The confidence interval' overlaps were low and $\mathrm{I}^{2}$ was $92 \%$

10. The confidence interval' overlaps were low and $\mathrm{I}^{2}$ was $86 \%$

11. The confidence interval' overlaps were low and $\mathrm{I}^{2}$ was $60 \%$

12. The confidence interval' overlaps were low and $I^{2}$ was $67 \%$

while their families need more patience and confidence to help support the patients $[8,21,28,36]$. This may be a future research direction in clinical practice to help improve cancer patients' education. 


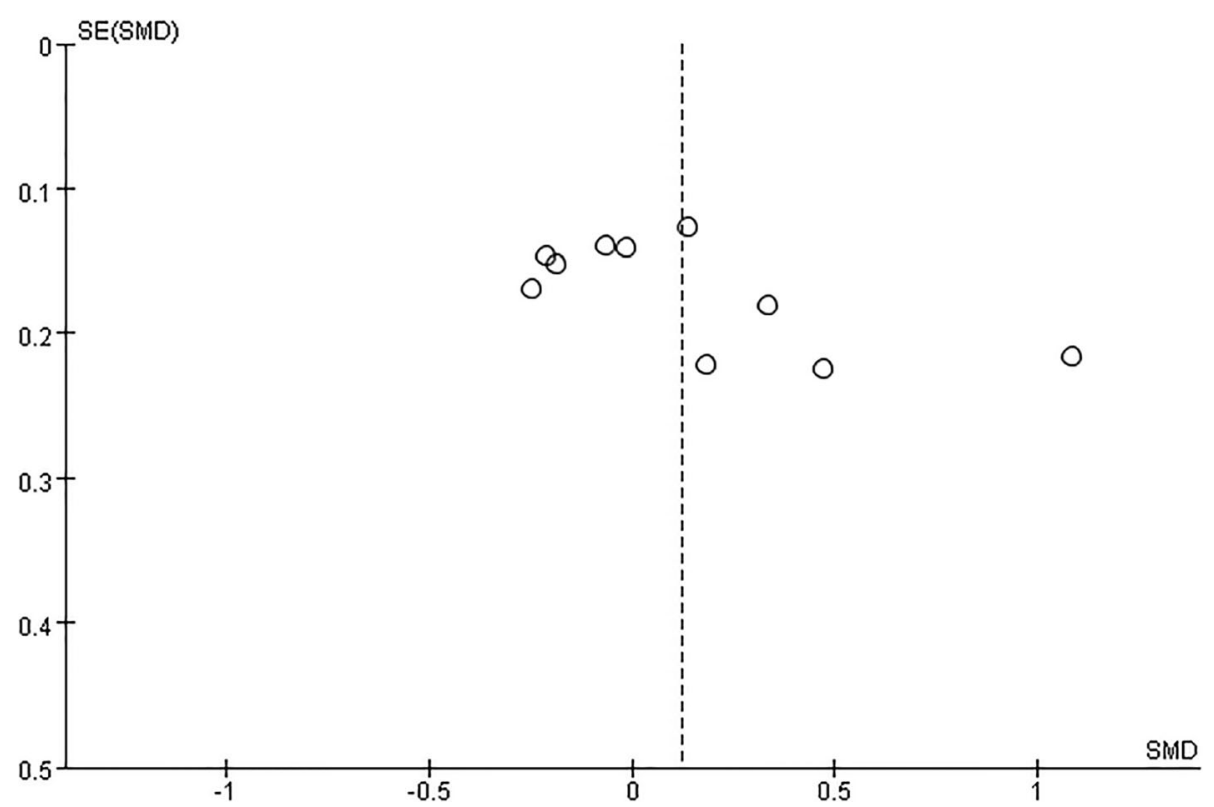

Fig. 9 Funnel plot in the meta-analysis of overall quality of life between totally informed of diagnosis and totally uninformed of diagnosis in cancer patients

\section{Implications for research}

This systematic review and meta-analysis of 23 trials examined whether a cancer patients level of information of their diagnosis affected their health-related quality of life. It provides evidence that a patients' knowledge of their diagnosis may have no effect on the general quality of life or on their symptoms of fatigue, pain, dyspnea, insomnia, appetite loss, physical function, role function, cognitive activity, and emotional function, and may in fact have beneficial effects in terms of vitality and social function.

Further research is required to evaluate the best way to tell patients the truth. Following on from the work of Ruifen Zhang 2016 [30], Fang Ding 2008 [15], and Xiuling Wang 2006 [12], we can suppose that delivering the truth to cancer patients combined with comprehensive nursing, especially mental health nursing, could be beneficial to their quality of life, however, whether it actually makes difference is still unknown. It would be helpful if there were more research on specific cancer types, such as lung, stomach, liver, colon, and breast, to determine if different outcomes on QoL are seen with different cancer types.

Quality of life is an important measure of cancer survival, but because of the quantities of scales, heterogeneity is large, which makes comparing findings between trials extremely difficult. To overcome this problem, health-related quality of life scales should be standardized in the future. Our results were consistent with the findings of Aggarwal A [7].

\section{Strengths and limitations of this study}

The results of this study will give clinicians and patients' family some enlightenment on communication with cancer patients. Our conclusion relies on both the quality and quantity of the original studies available for review, and the low-quality evidence in our studies may affect any extrapolation of our conclusion. Because our research went on for a long period of time, we conducted a complementary search to avoid missing the latest original studies. The biggest limitation in our study was the different health-related quality of life scales which increased heterogeneity and made comparing findings between trials extremely difficult. However, we were still able to analyze these continuous outcomes as standardized mean differences (SMD) between groups with 95\% CIs. To assess heterogeneity, we determined statistical heterogeneity using the $\mathrm{X}^{2}$ test. If heterogeneity was low (I2 $<50 \%, \mathrm{P}>0.05)$, we used the fixed effects model to calculate the combined effect and if heterogeneity was high (I2 $\geq 50 \%, P \leq 0$. 05), we used the random effects model to combine the studies. The sub-subgroups were then divided into lung, liver, and gastrointestinal cancer to decrease heterogeneity.

\section{Conclusion}

Informing cancer patients about their diagnosis may not have a detrimental effect on their quality of life, but more studies based on high quality evidence are still required.

\section{Abbreviations}

EORTC: European Organization for Research and Treatment of Cancer; GRADE: Grading of Recommendation, Assessment, Development and 
Evaluation; NOS: Newcastle-Ottawa Scale; SMD: Standardized mean difference

\section{Acknowledgements}

We would like to thank Dang Wei (the PhD candidate from Karolinska Institutet, Sweden.) for his invaluable assistance with his advice on data analysis.

\section{Authors' contributions}

Conceived and designed the research: MW, XL, JW and JZ. Performed the study (including literature search, classifying the CRs and extracting data):MW, XL, ZL,CC, JW. Analyzed data: MW, JW and MNL. Drafted the manuscript: MW and MNL. Modified the manuscript: JZ. All authors have read and approved the manuscript.

\section{Funding}

There was no financial support in the study.

\section{Availability of data and materials}

No additional data is available.

\section{Ethics approval and consent to participate}

Not applicable.

\section{Consent for publication}

Not applicable.

\section{Competing interests}

None.

\section{Author details}

'Dermatology Department of Xiangya Hospital, Central SouthUniversity, No.87, Xiangya Road, Kaifu District, Changsha 410000, Hunan Province, China. ${ }^{2}$ Maternity Department of Xiangya Hospital, Central South University, Lanzhou 730000, China. ${ }^{3}$ The Second Clinical Medical College of Lanzhou University, Lanzhou 730000, China.

Received: 1 February 2020 Accepted: 19 June 2020

Published online: 02 July 2020

\section{References}

1. GBD 2015 Risk Factors Collaborators. Global, regional, and national comparative risk assessment of 79 behavioral, environmental, and occupational, and metabolic risks or clusters of risks, 1990-2015: a systematic analysis for the Global Burden of Disease Study 2015. Lancet. 2016:388(10053):1659-724 JC Gao and YP Guo.

2. Annunziata MA, Foladore $S$, Magri MD, et al. Does the information level of cancer patients correlate with quality of life? A prospective study. Tumori. 1998;84:619-23.

3. Novack DH, Plumer R, Smith RL, et al. Changes in physicians' attitudes toward telling the cancer patient. JAMA. 1979;241:897-900.

4. Alexander P, Dinesh N, Vidyasagar M. Psychiatric morbidity among cancer patients and its relationship with awareness of illness and expectations about treatment outcome. Acta Oncol. 1993;32:623-6.

5. Hinton J. Can home care maintain an acceptable quality of life for patients with terminal cancer and their relatives? Palliat Med. 1994;8:183-96.

6. Finlayson CS, Chen YT, Fu MR. The Impact of Patients' Awareness of Disease Status on Treatment Preferences and Quality of Life among Patients with Metastatic Cancer: A Systematic Review from 1997-2014. J Palliat Med. 2015;18(2):176-86.

7. Sterne JA, Hernán MA, Reeves BC, et al. ROBINS-l: a tool for assessing risk of bias in non-randomised studies of interventions. BMJ. 2016;355:i4919.

8. Tanida N, Yamamoto N, Sashio H, et al. Influence of truth disclosure on quality of life in cancer patients. Int J Clin Oncol. 1998;3(6):386-91.

9. Bozcuk H, Erdoğan V, Eken C, et al. Does awareness of diagnosis make any difference to quality of life? Support Care Cancer. 2002;10(1):51-7.

10. Zou J, Qian J, Li R, et al. Research on the factors that affect the mood and quality of life of cancer patients. Chin J Cancer. 2006;15(11):719-22.

11. Liu $Z, X u Y$, Aiqin W. Analysis of related factors affecting the quality of life of cancer patients. Shandong Psychiatry. 2006;4:248-51.
12. Xiuling W. Comparative analysis of quality of life between informed nursing and confidential nursing in patients with liver cancer. Qilu Nurs J. 2006; 12(19):1908-9.

13. Oliveira A, Pimentel FL. Do patients know their diagnosis of cancer? Prog Palliat Care. 2006;14(6):260-4.

14. Zhao L, Huang J. A study on the correlation between informed status and quality of life of patients with primary liver cancer. J Nurs Sci. 2007;022(006): 8-10.

15. Fang $D$, Yongqian $X$. Influence of knowing the fact state of tumor patients on their quality of life and nursing care of them. Chin Nurs Res. 2008;115(7): $611-5$.

16. Zheng L, Han J, Wang Q. The effect of knowledge on the quality of life of patients with advanced gastric cancer. J Shanxi Med Coll Staff Work. 2009; 019(001):60-2.

17. Kong R. A clinical study on the impact of cancer patients' knowledge on survival and quality of life. Curr Nurs. 2009;1:48-9.

18. Li Z, Geng W, Wang M, et al. The effect of being informed or not on the quality of life of patients with advanced lung cancer. Clin Coll. 2009;024(011):982-3.

19. Montazeri A, Tavoli A, Mohagheghi AM, et al. Disclosure of cancer diagnosis and quality of life in cancer patients: should it be the same everywhere? BMC Cancer. 2009;9(1):1-8.

20. Xue X. Investigation of the malignant tumor's informed status and the effect on the psychosomatic body of patients under different informed conditions: Shandong University; 2011.

21. Fan X, Huang H, Luo Q, et al. Quality of life in Chinese home-based advanced Cancer patients: does awareness of Cancer diagnosis matter? J Palliat Med. 2011;14(10):1104-8.

22. Sun $Y$, Sun $B$, Huanran $D$, et al. The impact of knowing cancer diagnosis on quality of life in patients with gastrointestinal malignant tumor. Chin J Behav Med Brain Sci. 2012;21(8):709-11.

23. Luo J, Wu F, Zheng D. Influence of informed status on the quality of life of patients with advanced lung cancer. Cancer Res Prev Treat. 2012;039(007):855-9.

24. Wang L, Wang H. A study on the influence of young patients with gastric cancer on their quality of life and psychological status. J Nurs Train. 2013;23:2117-20.

25. Liping F, Yufen Z, Rongze $Z$, et al. The effect of informing the diagnosis in patients with the advanced lung cancer on their quality of life. Chin J Gerontol. 2013:33(12):2861-2

26. Feng Z, Zhang Z, Yin M, et al. Clinical observation of the effect of condition awareness on the quality of life of cancer patients with strong opioid analgesia. Cancer Pharm. 2014;000(001):59-61.

27. Li Y, Wu Y, Li W. Evaluating the quality of life of liver cancer patients in the state of receiving informed nursing and confidential nursing. Int J Nurs. 2014;000(007):16113.

28. Nakajima N, Kusumoto K, Onishi $\mathrm{H}$, et al. Does the approach of disclosing more detailed information of Cancer for the terminally ill patients improve the quality of communication involving patients, families, and medical professionals? Am J Hosp Palliat Care. 2014;99(7):10215-20.

29. Yang $\mathrm{B}$, Jiang $\mathrm{H}$. Effects of awareness of diagnosis on quality of life in elderly patients with advanced cancer. Hainan Med J. 2015;000(011):1595-1597,1598

30. Ruifen Z, Kun Z, Qian H, et al. Comparative analysis of quality of life between informed nursing and confidential nursing in patients with liver cancer. Electron J Clin Med Lit. 2016;3(16):3263.

31. Epplein M, Zheng $Y$, Zheng W, et al. Quality of life after breast Cancer diagnosis and survival. J Clin Oncol. 2011;29(4):406-12.

32. Sterba KR, Zapka J, Cranos C, et al. Quality of life in head and neck Cancer patient-caregiver dyads: a systematic review. Cancer Nurs. 2015;39(3):238.

33. Chirico A, Lucidi F, Merluzzi T, et al. A meta-analytic review of the relationship of cancer coping self-efficacy with distress and quality of life. Oncotarget. 2015;8(22): 36800-11.

34. Mosleh SM. Health-related quality of life and associated factors in Jordanian cancer patients: A cross-sectional study. Eur J Cancer Care. 2018;27:e12866.

35. Aggarwal AN, Singh N, Gupta D, et al. Does awareness of diagnosis influence health related quality of life in north Indian patients with lung cancer? Indian J Med Res. 2016;143(7):38.

36. Andruccioli J, Montesi A, Raffaeli W, et al. Illness awareness of patients in hospice: psychological evaluation and perception of family members and medical staff. J Palliat Med. 2007;10:741-8.

\section{Publisher's Note}

Springer Nature remains neutral with regard to jurisdictional claims in published maps and institutional affiliations. 